\title{
Suicide in the elderly: an epidemiologic study
}

\author{
Suicídio em idosos: um estudo epidemiológico \\ Suicidio en ancianos: un estudio epidemiológico
}

How to cite this article:

Santos MCL, Giusti BB, Yamamoto CA, Ciosak SI, Szylit R. Suicide in the elderly: an epidemiologic study. Rev Esc Enferm USP. 2021;55:e03694. doi: https:// doi.org/10.1590/S1980-220X2019026603694

\section{Mariana Cristina Lobato dos Santos ${ }^{1}$ \\ Barbara Bartuciotti Giusti ${ }^{2}$ \\ Clarissa Ayri Yamamoto ${ }^{1}$ \\ Suely Itsuko Ciosak ${ }^{2}$ \\ Regina Szylit ${ }^{1}$}

1 Universidade de São Paulo, Escola de Enfermagem, Departamento de Enfermagem Materno Infantil e

Psiquiátrica, São Paulo, SP, Brazil.

${ }^{2}$ Universidade de São Paulo, Escola de Enfermagem, Departamento de Enfermagem em Saúde Coletiva, São Paulo, SP, Brazil.

\begin{abstract}
Objective: To analyze the incidence and means of elderly suicide in Brazil. Method: Epidemiologic, cross-sectional, quantitative, and retrospective study. The data were obtained in a platform maintained by the Ministry of Health and analyzed. The mortality rate was calculated and means and percentages regarding the employed means of suicide were obtained. Results: In this period, 8,977 suicides took place among the population over 60 years. The highest suicide rates were concentrated in the population over 80 , which presented a mean 8.4/100,000 for this period, and between 70 and 79 years, with a mean rate of $8.2 / 100,000$. Considering the total elderly population over 60 years, this value reached $7.8 / 100,000$, whereas in the general population this was $5.3 / 100,000$. The values are always higher among the elderly population: the mean rate in the last five years among the elderly is $47.2 \%$ higher than the mean for the general population. The main mean of suicide was hanging (68\%), followed by firearm (11\%) self-intoxication (9\%), falling from a high place $(5 \%)$, and undefined or undetermined means (6\%). Conclusion: Epidemiologic analyses bring visibility to the dyad aging and suicide, corroborating the pertinence of this theme.
\end{abstract}

DESCRIPTORS

Aged; Suicide; Epidemiology; Geriatric Nursing. 


\section{INTRODUCTION}

The challenges posed by the progressive aging of the world population are under discussion both in the academic literature and in the diverse sectors of society in the last decades. According to the World Health Organization (WHO), the number of people older than 60 years will amount to 2 billion in 2050, representing thus one fifth of the world's population. The Brazilian Institute of Geography and Statistics (Instituto Brasileiro de Geografia e Estatistica-IBGE) ${ }^{(1)}$ points out that, in 2016, Brazil had the fifth largest elderly population in the world ${ }^{(2)}$ and that, by 2030 , the number of elderly people will have surpassed the total number of children between zero and fourteen years old ${ }^{(1)}$.

A longer life may bring auspicious perspectives: more time to dedicate to relatives, friends, and passions, as well as to enjoy achievements and engage in new objectives. Such positive aging experience, nonetheless, is only possible if lived with health and quality of life.

The aging process should be integrated to daily life, physical limitation, sickness, and changes in the composition of the social and family network, giving new meaning to forms of living and the suffering related to progressive losses through an outlook of growth and evolution. Some elders, however, may express ongoing difficulties, which crystalize and may evolve to melancholy, depression, and suicide ${ }^{(3)}$.

The elderly are considered the population group with the highest risk of suicide in the whole world. Despite this, this phenomenon still receives little attention from authorities in the public health area, researchers, and the media, which tend to prioritize younger population groups in their rationale and actions ${ }^{(4)}$.

Risk factors for suicide among the elderly include social isolation, lack of a support network, solitude, grief due to loss of a partner and offspring, pathologies related to frailty, conditions of dementia, depression, ideation, previous attempts, and access to the means ${ }^{(4-6)}$.

Suicide is a self-annihilation act associated to the perception of death as the best solution to escape unbearable psychic pain. Suicide hence stems from personal decisions but is influenced by social and microsocial factors ${ }^{(3)}$.

Estimations point out that over 800,000 people perish from suicide every year and that for each adult committing suicide at least other twenty attempt to take their own life $\mathrm{e}^{(7)}$. In Brazil, around 10,000 people die by suicide per year; these values have been stable in recent years. The mean coefficient of death by suicide in the period 2004-2010 was 5.7/100,000 (7.3/100,000 for males and 1.9/100,000 for females); when compared to those of other countries, these values might be considered low. However, the data identified in the series from 1994 to 2004 show that some Brazilian states currently present rates comparable to those of countries with an average to high suicide rate - especially among the elderly ${ }^{(8-10)}$.

Considering the high suicide rates among the elderly, translated through the presented epidemiological data, and the growth of the elderly population, their vulnerabilities, and the reduced attention towards mental health issues, the pertinence of this study is justified.

According to the $\mathrm{WHO}$, suicides are avoidable. There is a series of preventive measures against suicide and suicide attempts as universal strategies, which are intricate and selective. These strategies include promotion of education and training of health professionals, especially those who are not mental health specialists, and professionals from other areas, such as professors and media professionals, aiming at a safe dissemination of information and public awareness. Reducing access to means (such as pesticides, firearms, and certain medications) is also important, as are health surveillance and improvements in obtaining and analyzing data on suicide and suicide attempts ${ }^{(11)}$.

Thus, this study aims to analyze the incidence and means in elderly suicide in Brazil.

\section{METHOD}

\section{DESIGN OF STUDY}

Epidemiologic, cross-sectional, quantitative, retrospective research.

\section{DATA COLLECTION}

The data on elderly suicide were collected from the Ministry of Health's System of Information on Mortality (Sistema de Informaçôes de Mortalidade do Ministério da Saúde-SIM/MS) available in the Unified Health System's Statistics Department (Departamento de Estatística do SUS - DATASUS) website ${ }^{(12)}$.

The DATASUS is responsible for administering and disseminating health information, epidemiological indicators, and information on morbimortality and demographics. This public domain information is accessed through the online interface TABNET, a statistical program elaborated for quick tabulation of health information provided by the Brazilian Ministry of Health.

The collection was conducted in June and July 2019 and included data from 2012 to 2016.

\section{ENROLLMENT CRITERIA}

Suicide data of people of both sexes who were 60 or older. The 10th review of the International Classification of Diseases (ICD), codes X60 to X84, was employed for identifying means of suicide. The ICD with similar means of suicide were grouped for a better analysis of the phenomenon; the data are thus presented following the organization presented in Chart 1. 
Chart 1 - ICD referring to different means of suicide, grouped by similarity or low incidence (less than 1\%) - São Paulo, SP, Brazil, 2019.

\begin{tabular}{|c|c|c|}
\hline ICD & Definition and Groupings & \\
\hline X60 & Nonopioid analgesics, antipyretics and antirheumatics & \multirow{11}{*}{ Self-poisoning } \\
\hline X61 & Antiepileptic, sedative, hypnotic, antiparkinsonian, and psychotropic drugs, not elsewhere classified & \\
\hline X61 & Narcotics and psychodysleptics [hallucinogens], not elsewhere classified & \\
\hline X62 & Narcotics and psychodysleptics [hallucinogens], not elsewhere classified & \\
\hline X63 & Other drugs acting on the autonomic nervous system & \\
\hline X64 & Other and unspecified drugs, medicaments, and biological substances & \\
\hline X65 & Intentional by alcohol & \\
\hline X66 & Organic solvents and halogenated hydrocarbons and their vapors & \\
\hline X67 & Other gases and vapors & \\
\hline X68 & Intentional exposure to pesticides & \\
\hline X69 & Other and unspecified chemicals and noxious substances & \\
\hline $\mathrm{X} 72$ & Intentional self-harm by handgun discharge & \multirow{3}{*}{ Firearms } \\
\hline $\mathrm{X} 73$ & Intentional self-harm by rifle, shotgun, and larger firearm discharge & \\
\hline $\mathrm{X} 74$ & Intentional self-harm by other and unspecified firearm discharge & \\
\hline $\mathrm{X} 78$ & Intentional self-harm by sharp object & \multirow{2}{*}{ Cutting or contusive object } \\
\hline X79 & Intentional self-harm by blunt object & \\
\hline X75 & Intentional self-harm by explosive material & \multirow{5}{*}{$\begin{array}{l}\text { Other means (low } \\
\text { incidence) }\end{array}$} \\
\hline $\mathrm{X} 77$ & Intentional self-harm by steam, hot vapors, and hot objects & \\
\hline X81 & Intentional self-harm by jumping or lying before moving object & \\
\hline X82 & Intentional self-harm by crashing of motor vehicle & \\
\hline $\mathrm{X} 83$ & Intentional self-harm by other specified means & \\
\hline ICD & \multicolumn{2}{|l|}{ Non-grouped ICD } \\
\hline $\mathrm{X} 70$ & Intentional self-harm by hanging, strangulation, and suffocation & \\
\hline $\mathrm{X} 71$ & Intentional self-harm by drowning and submersion & \\
\hline $\mathrm{X} 76$ & Intentional self-harm by smoke, fire, and flames & \\
\hline X80 & Intentional self-harm by jumping from a high place & \\
\hline X84 & Intentional self-harm by unspecified means & \\
\hline
\end{tabular}

\section{Data tREATMENT AND ANALYSIS}

When calculating suicide mortality rates, the numerator was the number of deaths by suicide taking place that year and the denominator was the population estimate by age group in Brazil, provided by the Foundation Brazilian Institute of Geography and Statistics ${ }^{(1)}$ for that year. Sexes (male and female) and age groups of the elderly population (60 to 69 years, 70 to 79 years, and 80 years or older) were taken into account and were also related to the general population data.

Thus, the incidence of suicide in the elderly in Brazil was analyzed from the rates (number of suicides/number of citizens multiplied by 100,000 ) and their temporal evolution between 2012 and 2016. The mean suicide rate for the period by age group and in the general population was also calculated, as well as the proportion of use of different means of suicide by the elderly and by the general population per sex.

\section{ETHICAL ASPECTS}

Since this study is based on secondary, free-access data, a submission to the Research Ethics Committee was not required.

\section{RESULTS}

The highest suicide rates were concentrated in the population over 80 years, which represented a mean 8.4/100.000 citizens in that period, and between 70 and 79 years old, with a mean rate of $8.2 / 100,000$. Considering the total elderly population over 60 , the mean suicide rate was $7.8 / 100,000$, whereas in the general population this value was $5.3 / 100,000$. The values were thoroughly higher among the elderly population: the mean rate for the elderly in the last 5 years is $47.2 \%$ higher than the mean for the general population.

Data on the suicide rate of the general population, the elderly (population over 60), elderly between 60 and 69 years, between 70 and 79 years, and 80 years or older per sex, from 2012 to 2016, are presented in Table 1. 
Table 1 - Total suicides and suicide rate among the elderly (population over 60 years old) and the general population from 2012 to 2016 in Brazil - São Paulo, SP, Brazil, 2019.

\begin{tabular}{|c|c|c|c|c|c|c|c|}
\hline \multirow{2}{*}{ Year } & \multirow{2}{*}{ Age group } & \multicolumn{3}{|c|}{ Number of suicides (all means) } & \multicolumn{3}{|c|}{ Coefficient of mortality rate by 100,000 citizens } \\
\hline & & Male & Female & Total* & Male & Female & Total \\
\hline \multirow{5}{*}{2012} & $60-69$ years & 721 & 195 & 916 & 13.5 & 3.2 & 7.7 \\
\hline & 70-79 years & 394 & 98 & 492 & 14.1 & 2.7 & 7.8 \\
\hline & 80 years or older & 221 & 40 & 262 & 19.2 & 2.2 & 9 \\
\hline & Total - Elderly & 1,336 & 333 & 1,670 & 14.4 & 2.9 & 8.0 \\
\hline & General Population & 8,061 & 2,257 & 10,321 & 8.5 & 2.3 & 5.2 \\
\hline \multirow{5}{*}{2013} & $60-69$ years & 693 & 211 & 904 & 12.0 & 3.1 & 7.2 \\
\hline & $70-79$ years & 428 & 100 & 528 & 15.2 & 2.7 & 8.1 \\
\hline & 80 years or older & 203 & 55 & 258 & 17.7 & 2.9 & 8.5 \\
\hline & Total - Elderly & 1,324 & 366 & 1,690 & 13.6 & 3 & 7.7 \\
\hline & General Population & 8,309 & 2,223 & 10,533 & 8.4 & 2.3 & 5.2 \\
\hline \multirow{5}{*}{2014} & $60-69$ years & 730 & 177 & 907 & 12.0 & 2.5 & 6.9 \\
\hline & $70-79$ years & 416 & 96 & 512 & 14.3 & 2.5 & 7.6 \\
\hline & 80 years or older & 218 & 41 & 259 & 18.3 & 3.1 & 8.2 \\
\hline & Total - Elderly & 1,364 & 314 & 1,678 & 13.4 & 2.4 & 7.3 \\
\hline & General Population & 8,419 & 2,233 & 10,653 & 8.4 & 2.2 & 5.3 \\
\hline \multirow{5}{*}{2015} & $60-69$ years & 806 & 243 & 1,049 & 12.7 & 3.3 & 7.7 \\
\hline & $70-79$ years & 507 & 109 & 616 & 16.8 & 2.7 & 8.8 \\
\hline & 80 years or older & 240 & 38 & 278 & 19.2 & 1.8 & 8.4 \\
\hline & Total - Elderly & 1,553 & 390 & 1.943 & 14.7 & 2.9 & 8.1 \\
\hline & General Population & 8,780 & 2,396 & 11,178 & 8.7 & 2.3 & 5.5 \\
\hline \multirow{5}{*}{2016} & $60-69$ years & 877 & 227 & 1,104 & 13.3 & 3.0 & 7.8 \\
\hline & $70-79$ years & 521 & 100 & 621 & 16.6 & 2.4 & 8.6 \\
\hline & 80 years or older & 241 & 40 & 271 & 17.8 & 1.9 & 7.8 \\
\hline & Total - Elderly & 1,639 & 367 & 1,996 & 14.8 & 2.6 & 8.0 \\
\hline & General Population & 9,053 & 2,378 & 11,433 & 8.9 & 2.3 & 5.5 \\
\hline \multirow{5}{*}{$\begin{array}{c}\text { Total }(2012 \\
\text { to } 2016)\end{array}$} & $60-69$ years & 3,827 & 1,053 & 4,880 & 12.7 & 3.0 & 7.7 \\
\hline & $70-79$ years & 2,266 & 503 & 2,769 & 15.4 & 2.6 & 8.2 \\
\hline & 80 years or older & 1,123 & 214 & 1,328 & 18.4 & 2.3 & 8.4 \\
\hline & Total - Elderly & 7,216 & 1,770 & 8,977 & 14.2 & 2.8 & 7.8 \\
\hline & General Population & 42,622 & 11,105 & 54,118 & 8.6 & 2.3 & 5.3 \\
\hline
\end{tabular}

* The total differs from the sum of men and women due to the existence of death registries with no sex.

Source: DATASUS, 2019.

The temporal evolution in the suicide rate of both sexes between 60 and 69 years, between 70 and 79 years, and 80 years or older in Brazil between 2012 and 2016 is presented in Figure 1.

The rate for 2016 is $5.7 \%$ higher than that of 2012 in the general population, whereas the values in the elderly population, despite wavering (with a 9\% reduction in 2014), were maintained in 2012 and $2016-8.0 / 100,000$. However, when considering the distribution of both sexes, a remarkably different perspective emerges. The suicide rate per sex in the elderly population (older than 60 years) and in the general population between 2012 and 2016 are presented in Figure 2. 


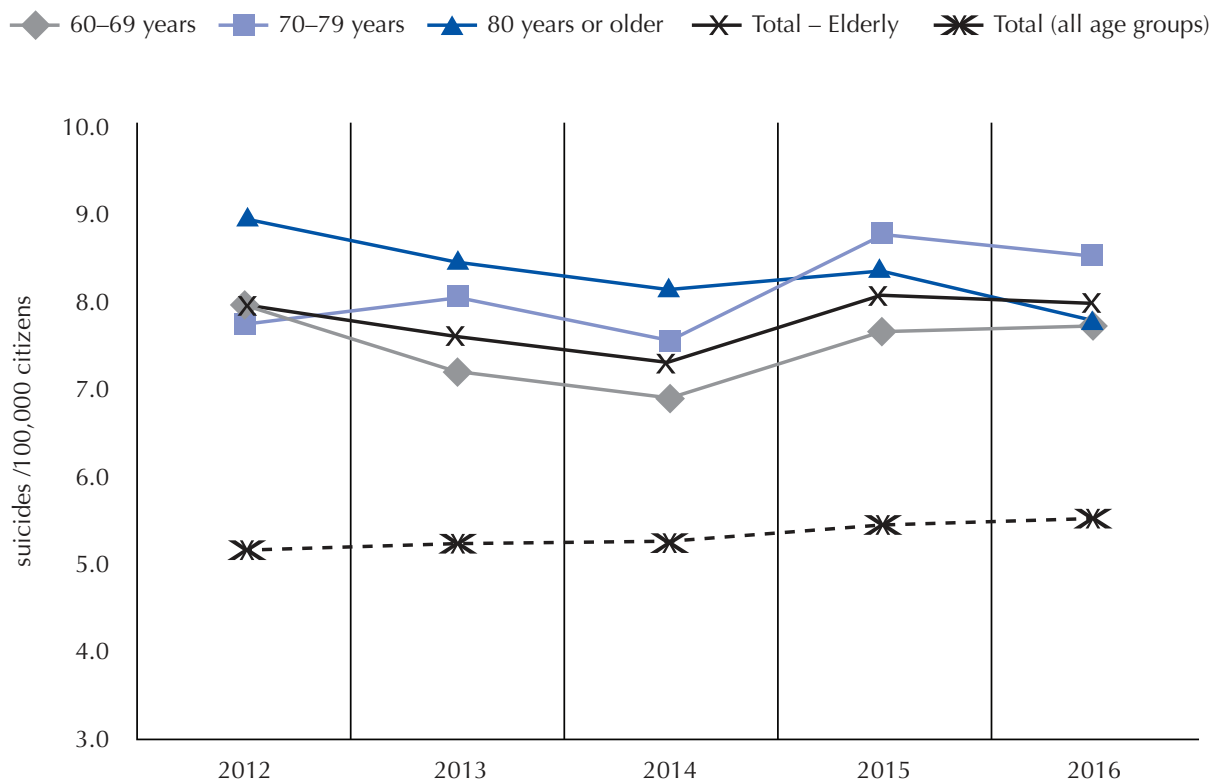

Source: DATASUS, 2019.

Figure 1 - Evolution of elderly suicide rate in both sexes (population over 60 years old) and in the general population in Brazil from 2012 to 2016.

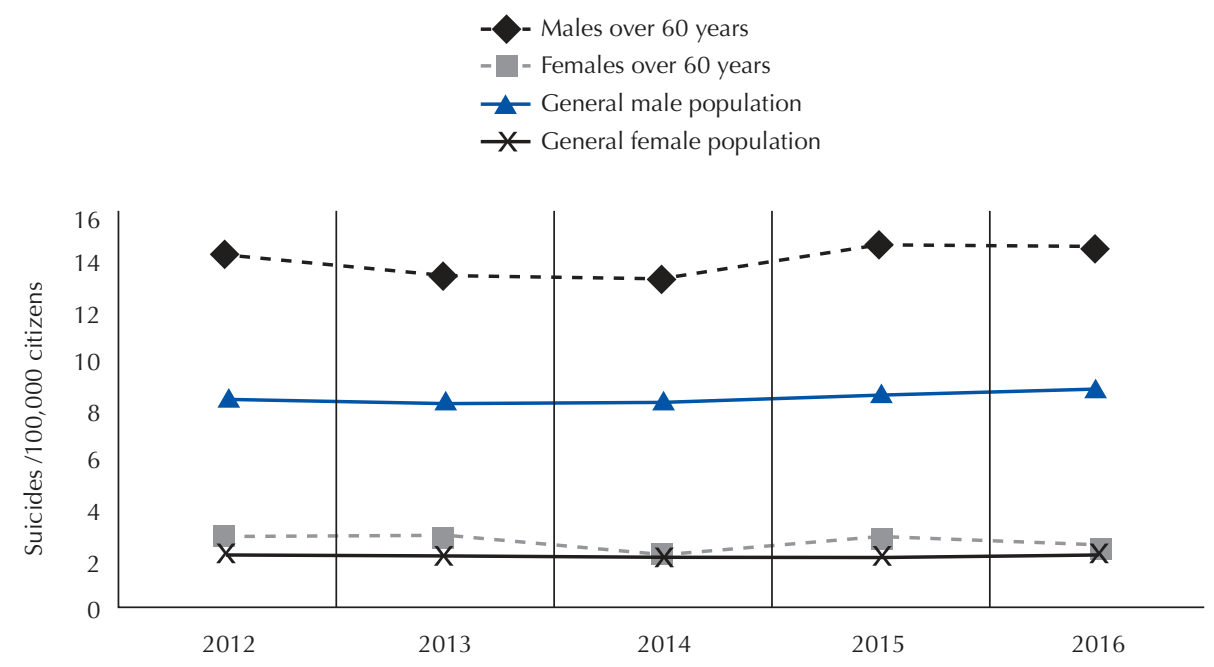

Source: DATASUS, 2019.

Figure 2 - Suicide rate (number of suicides per 100,000 citizens) per sex for elderly and general populations between 2012 and 2016.

Among elderly men, there was a $2.8 \%$ increase (from $14.4 / 100,000$ to $14.8 / 100,000$ ) in suicide rates in this period, whereas among elderly women there was a $10.3 \%$ reduction (from 2.9/100,000 to 2.6/100,000). Among the general male population, this increase was of $4.7 \%$ (from $8.5 / 100,000$ to $8.9 / 100,000)$ and, among the general female population, the values were stable $(2.3 / 100,000)$. Both for the elderly and general population, this increase is noted to have occurred exclusively for the male population.
Regarding the means used in elderly suicide, the proportion of deaths by hanging, firearm, drowning, and other means maintained stability in the last 5 years. These data, however, diverge considerably between men and women. The data on the proportion of use of different means of suicide between elderly men and women from 2012 to 2016 is observed in Figure 3. 


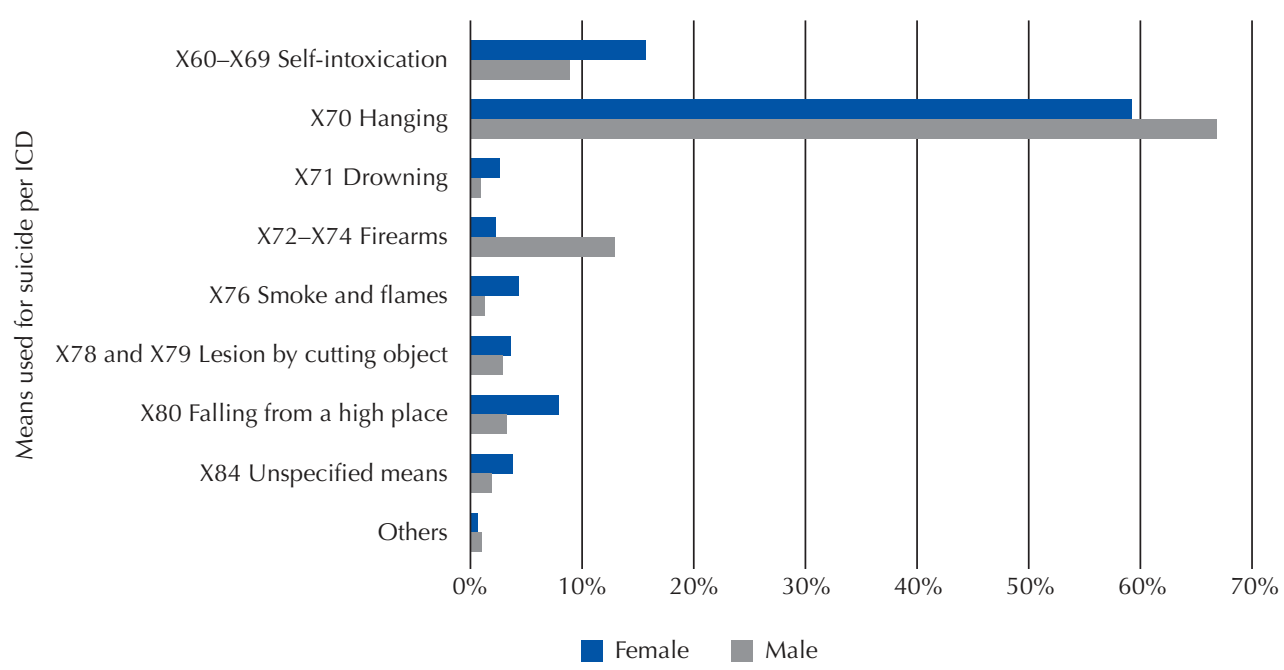

Source: DATASUS, 2019

Figure 3 - Proportion of use of different means of suicide among men and women older than 60 years from 2012 to 2016 per ICD.

Among elderly people of both sexes, hanging was the most used mean throughout the studied period (67\% for men and 59\% for women); the same pattern is observed for the general population.

The other means diverge between men and women: for elderly men, firearms occupy the second place (13\%), followed by self-intoxication (9\%), injuries with cutting objects and falling from a high place (both with $3 \%$ ), and unspecified means (2\%). Drowning, fire and flames, and other means had only $1 \%$.

Among elderly women, self-intoxication is in the second position (18\%); third position is falling from a high place (10\%). Self-provoked injuries by smoke, fire, and flames are in fourth place (5\%), and intentional self-provoked injuries with cutting object and piercing object, self-provoked injuries by drowning, as well as firearms, are equally responsible for $3 \%$ of suicides in elderly women.

Among the substances used for self-intoxication, the most used among elders of both sexes are pesticides (43\%), followed by medications (25.1\%), and chemical products and unspecified harmful substances (23.7\%). Within self-intoxication by medication, the most used ones are unspecified (49.8\%), antiepileptic, sedative, hypnotic and antiparkinsonian drugs (40.1\%), and anti-inflammatory (4.8\%).

\section{DISCUSSION}

Studies dated from the twentieth century brought considerations on the main factors associated to ideation, attempts, and suicide itself, considering the complexity and association of physical, social, mental, and biological factors. However, the fact that suicide is more incident in the elderly population is little explored ${ }^{(13-15)}$.

According to the WHO's Global Report for Suicide Prevention, published in 2014 ${ }^{(11)}$, the highest suicide rates worldwide are those of people over 70 years old, corroborating this study, in which the values for the suicide rate were thoroughly higher among the elderly population: the mean for the last five years among the elderly is $47.2 \%$ higher than that of the general population.
In this study, it is evident that, in Brazil, the highest suicide rates are concentrated in the populations above 80 and between 70 and 79 years. A study conducted in Southern Brazil also provides evidence for these results and points that the principal means of suicide used in older age is hanging. Although suicide in that region has reduced, it has temporally increased among the older elderly population ${ }^{(4,16)}$.

Considering the numbers related to the older elderly and the prevention programs suggested by the $\mathrm{WHO}$, it is necessary to investigate the younger elderly, since studies show that the reasons for suicide attempts may be related to economic crises, social role, and loneliness. Acting timely may be crucial to prevent suicide with increased age ${ }^{(4,17-20)}$.

According to the Brazilian Society of Geriatrics and Gerontology, the elderly have the smallest number of attempts; however, one in every four attempts lead to death, an attempt/suicide ratio much higher than that of the general population $^{(5,18,21)}$.

The number of suicides has been increasing in diverse parts of the world, leading the UN/PAHO to recognize suicide and its attempts as a priority in the global health agenda, encouraging countries to develop and reinforce prevention strategies as part of the Sustainable Development Goals agenda, specifically goal $3.4^{(22)}$.

This study shows that, both in the elderly and general populations, this increase was exclusive to men: among elderly men, there was a $2.3 \%$ increase in suicide rates. Men are believed to display more competitive and rasher behaviors than women, while presenting higher alcohol and drug consumption, which are considered risk factors for suicide ${ }^{(3-5)}$.

Importantly, this study found a $10.3 \%$ decrease in female elderly suicide; among women in the general population, the values maintained stability. This is an understudied phenomenon, although it is known that, except for China, it is predominant among men of all age groups. The paradox of gender in suicide - women attempt more, but men die from suicide more frequently - has been attributed to the latter's 
use of more lethal means, in addition to a social demand for rasher and more daring attitudes ${ }^{(6,20,23)}$.

Also, women can be inferred to seek health services more often and to be better at dealing with issues related to stigma, prejudice, and taboo, which, by its turn, enables mental health care to be more often provided to this population. The maintenance of social roles, such as those of mother and grandmother, does not apply to men, who frequently lose their family provider role as they age; such factor also seems to strongly impact the paradox of gender in suicide during aging ${ }^{(20,23)}$.

Concerning the means of suicide, hanging was the most used one in both sexes. Studies show that this is chosen due to its easy access, potential for lethality, and generally insufficient time for care provision. The means used by the elderly tend to be more lethal than those used by young people and, in general, are employed at home, which may hinder preventive measures which suggest restriction of means ${ }^{(3,6,8)}$.

When analyzing the results, other means are noticed to differ between men and women. An epidemiological study suggests that this difference may be explained historically by higher access of men to more lethal means and by the smaller exposure of women to the sentiment of failure due to financial misfortunes, competition, and rashness ${ }^{(19,23-24)}$.

Firearms are second place in this study. According to the research Global Mortality from Firearms ${ }^{(25)}$, Greenland had the smallest rate of suicides caused by firearms: 22 per 100,000 citizens. The United States were in the second place; $50.57 \%$ of its suicides employed this means. Such choice is intimately related to its lethality potential and the higher access of men to guns ${ }^{(12,26)}$.

Self-intoxication is in the second position among women and in the third position among men. Studies report that many suicide attempts employ such means; due to this, the integration of actions of promotion, prevention, and reporting of these occurrences are fundamental to avoid reattempts and death from suicide. Previous attempts are risk factors for death ${ }^{(11)}$.

In the present study, pesticides were used in $43 \%$ of selfintoxication deaths. Another Brazilian study found that $40 \%$ of death and suicides in the general population are due to pesticides commercialized illegally, suggesting insufficient control and inspection in $\mathrm{Brazil}^{(7)}$.

Prescribed and non-prescribed medication are also an important factor. A Brazilian study highlighted dipyrone as the most frequent substance in suicide attempts in the general population, differently from other countries, where paracetamol and salicylates occupy the first places in proportions like those of antidepressants and tranquilizers ${ }^{(27)}$. This study has identified that the most used medications were antiepileptic, sedatives, hypnotics, antiparkinsonians, psychotropic, and non-specified drugs. The elderly have access to diverse prescribed substances and a higher disease burden increases the probability of unnecessary consumption of medication, suggesting what is called polypharmacy. Pharmacological combinations may pose dangers of adverse reactions. In addition, contraindicated drug interaction may increase the risk of death due to overdose and suicide ${ }^{(28)}$.

Suicide by lesions from cutting objects, falling from a high place, unspecified means, drowning, fire and flames, and others amount to less than $3 \%$ of the means of suicide employed by this population; however, these require special attention, since, even if they represented only one case, their outcome is always death. In other age groups, lesions with cutting objects add to expressive numbers in suicide rates ${ }^{(12)}$.

Regarding death certificates, the data may be underreported, varying with the declarant's perspective. Many taboos and bureaucratic difficulties are found in this context, such as an idealized image of the post-mortem, bureaucracy related to life insurance, and the need for causal precision ${ }^{(29)}$. Underreporting is a challenge which must be overcome to enable trustworthy epidemiological analysis, supporting thus efficient care strategies.

Apparently, death by hanging presents the smallest possibility of underreporting, since the intention for the death is usually clearer. Self-intoxication and death by firearms are frequently registered as indeterminate intention, as are falling and drowning ${ }^{(16)}$. In 2009, reporting cases of suicide attempt became mandatory. The inclusion of this aggravation in the immediate reporting list is justified by the objective of measuring the magnitude of this phenomenon and foster fast decision making, such as forwarding and registration of patients in the psychosocial care network services.

The results found denote the need for actions aimed at this population. Recently, Law 13.819/April 2019 was enacted; it deals with the National Policy for the Prevention of Self-harm and Suicide. This law is expected to lead to actions related to the promotion of mental health, prevention of self-provoked violence, and strengthening of psychosocial care which emphasizes mental healthcare. Multidisciplinary approaches based on the community, involving initial interventions such as reception, identification of risk, and followup, are included among the most recommended approaches ${ }^{(30)}$.

Diverse studies deal with population aging and suicide in general; however, few have considered this dyad in scientific publication, approaching specially the employed means of suicide. This fact weakens the discussion and is one of this study's limitations. Also, the epidemiological data provided by DATASUS have frailties regarding time between collection and publication and quality, considering the underreporting of suicide in Brazil.

Given this, the results found in this study might deepen initiatives which give visibility to this theme and subsequently foster actions to guarantee singularity regarding the elderly.

\section{CONCLUSION}

This epidemiological analysis has revealed important data, giving visibility to this problem. One death by suicide is severe by itself and brings forth many questions: what kind of suffering can be strong enough to have death itself as outcome? What could have been done differently?

Given these difficulties, in addition to restrictions to means of suicide, the alternatives would include professional education, discussion of public policies and, especially, care of elders as a whole, considering that, in many cases, depression emerges in an atypical form. A deficient approach to elderly psychic suffering is reflected in the data presented here. Hence, a special outlook towards the dyad elderlymental health is undoubtedly required. 
RESUMO

Objetivo: Analisar a incidência e os meios usados no suicídio de idosos no Brasil. Método: Pesquisa epidemiológica, transversal, quantitativa e retrospectiva. Os dados foram obtidos em uma plataforma do Ministério da Saúde e analisados. Calculou-se o coeficiente de mortalidade e foram obtidas médias e percentuais quanto aos meios utilizados. Resultados: No período, ocorreram 8.977 suicídios na população acima de 60 anos. As taxas de suicídio mais elevadas concentram-se na população acima de 80 anos, que apresentou média de 8,4/100.000 no período, e entre 70 e 79 anos, com taxa média de 8,2/100.000. Considerando-se a totalidade da população idosa acima de 60 anos, o valor chegou a 7,8/100.000, enquanto na população geral ficou em 5,3/100.000. Os valores mantêm-se sempre superiores entre a população idosa: a taxa média dos últimos 5 anos entre idosos é $47,2 \%$ superior à média da população geral. O principal meio foi enforcamento (68\%), seguido por arma de fogo (11\%), autointoxicações (9\%), precipitação de lugar elevado (5\%) e meios indefinidos ou indeterminados (6\%). Conclusão: Análises epidemiológicas trazem visibilidade ao binômio envelhecimento e suicídio, corroborando a pertinência do tema.

\section{DESCRITORES}

Idoso; Suicídio; Epidemiologia; Enfermagem Geriátrica.

\section{RESUMEN}

Objetivo: Analizar la incidencia y los medios de suicidio utilizados por ancianos en Brasil. Método: Estudio epidemiológico, transversal, cuantitativo y retrospectivo. Los datos se obtuvieron de una plataforma del Ministerio de Sanidad y se analizaron. Se calculó el coeficiente de mortalidad y se obtuvieron los promedios y porcentajes de los medios utilizados. Resultados: En el periodo, se produjeron 8.977 suicidios en la población mayor de 60 años. Las tasas de suicidio más elevadas se concentraron en la población mayor de 80 años, que tuvo una media de 8,4/100.000 en el periodo, y entre 70 y 79 años, con una tasa media de 8,2/100.000. Considerando el conjunto de la población anciana mayor de 60 años, la cifra alcanzó el 7,8/100.000, mientras que en la población general fue del 5,3/100.000. Los valores se mantuvieron más altos entre la población anciana: la tasa media de los últimos 5 años entre los ancianos es un 47,2\% superior a la media de la población general. El principal medio de suicidio fue el ahorcamiento (68\%), seguido de las armas de fuego (11\%), la autointoxicación (9\%), alturas (5\%) y los medios indefinidos o indeterminados (6\%). Conclusión: Los análisis epidemiológicos aportan visibilidad al binomio envejecimiento y suicidio, corroborando la relevancia del tema.

\section{DESCRIPTORES}

Anciano; Suicidio; Epidemiología; Enfermería Geriátrica.

\section{REFERENCES}

1. Instituto Brasileiro de Geografia e Estatística. Síntese de indicadores sociais: uma análise das condições de vida da população brasileira: 2016 [Internet]. Rio de Janeiro: IBGE; 2016 [citado 2019 jun. 15]. Disponível em: https://biblioteca.ibge.gov.br/visualizacao/livros/ liv98965.pdf

2. Organização Mundial da Saúde. Relatório Mundial de Envelhecimento e Saúde [Internet]. Genebra: OMS; 2015 [citado 2019 jun. 15]. Disponível em: http://sbgg.org.br/wp-content/uploads/2015/10/OMS-ENVELHECIMENTO-2015-port.pdf

3. Sousa GS, Silva RM, Figueiredo AEB, Minayo MCS, Vieira LJES. Circunstâncias que envolvem o suicídio de pessoas idosas. Interface (Botucatu). 2014;18(49):389-402. doi: http://dx.doi.org/10.1590/1807-57622013.0241

4. Pinto LW, Pires TO, Silva CMFP, Assis SG. Evolução temporal da mortalidade por suicídio em pessoas com 60 anos ou mais nos estados brasileiros, 1980 a 2009. Ciênc Saúde Coletiva. 2012;17( 8 ):1973-81. doi: http://dx.doi.org/10.1590/s1413-81232012000800008

5. Ciulla L, Nogueira EL, Silva Filho IG, Tres GL, Engroff P, Ciulla V, et al. Suicide risk in the elderly: data from Brazilian public health care program. J Affect Dis. 2014;152:513-6. doi: https://doi.org/10.1016/j.jad.2013.05.090

6. Zhang W, Ding H, Su P. Does disability predict attempted suicide in the elderly? A community-based study of elderly residents in Shanghai, China. Aging Ment Health. 2016;20(1):81-7. doi: https://doi.org/10.1080/13607863.2015.1031641

7. Brasil. Ministério da Saúde; Secretaria de Vigilância em Saúde. Suicídio: saber, agir e prevenir. Perfil epidemiológico das tentativas e óbitos por suicídio no Brasil e a Rede de Atenção à Saúde [Internet]. Brasília; 2017 [citado 2019 jun. 15]. Disponível em: http://portalarquivos2. saude.gov.br/images/pdf/2017/setembro/21/2017-025-Perfil-epidemiologico-das-tentativas-e-obitos-por-suicidio-no-Brasil-e-a-rede-deatencao-a-saude.pdf

8. Botega NJ. Comportamento suicida: epidemiologia. Psicol USP. 2014;25(3);231-6. doi: http://dx.doi.org/10.1590/0103-6564d20140004

9. Marín-León L, Oliveira HB, Botega NJ. Suicide in Brazil, 2004-2010: the importance of small counties. Rev Panam Salud Pública. 2012;32(5):351-9.

10. Minayo MCS, Cavalcante FG. Suicide in elderly people: a literature review. Rev Saúde Pública. 2010; 44(4):750-7. doi: https://doi. org/10.1590/S0034-89102010000400020

11. World Health Organization (WHO). Preventing suicide: a global imperative [Internet]. Geneva: WHO; 2014 [cited 2019 June 15]. Available from: http://apps.who.int/iris/bitstream/handle/10665/131056/9789241564779_eng.pdf?sequence=1

12. Brasil. Ministério da Saúde. DATASUS. Sistema de Informações sobre Mortalidade [Internet]. Brasília; 2016 [citado 2019 mar. 6]. Disponível em: http://www2.datasus.gov.br/DATASUS/index.php?area=0205\&VObj=http://tabnet. datasus.gov.br/cgi/deftohtm.exe?sim/cnv/ext10

13. Machado DB, Santos DN. Suicídio no Brasil, de 2000 a 2012. J Bras Psiquiatr. 2015;64(1):45-54. doi: http://dx.doi.org/10.1590/00472085000000056

14. Kumar P.NS, Anish PK, George B. Risk factors for suicide in elderly in comparison to younger age groups. Indian J Psychiatry. 2015;57(3):249-54. doi: http://dx.doi.org/10.4103/0019-5545.166614

15. Teixeira RR. Três fórmulas para compreender "O suicídio" de Durkheim. Interface (Botucatu). 2002;6(11):143-52. doi: http://dx.doi. org/10.1590/S1414-32832002000200021

16. Rosa NM, Oliveira RR, Arruda GO, Mathias TAF. Mortalidade por suicídio no Estado do Paraná segundo meios utilizados: uma análise epidemiológica. J Bras Psiquiatr. 2017;66(2):73-82. doi: http://dx.doi.org/10.1590/0047-2085000000153 
17. Cerqueira CJL, Passos ALV, Araújo LF, Oliveira JV. Análise psicossocial do envelhecimento entre idosos: as suas representações sociais. Actual Psicol. 2020;34(128):1-15. doi: https://doi.org/10.15517/ap.v34i128.35246

18. Stanley IH, Hom MA, Rogers ML, Hagan CR, Joiner Jr TE. Understanding suicide among older adults: a review of psychological and sociological theories of suicide. Aging Ment Health. 2016;20(2):113-22. doi: https://doi.org/10.1080/13607863.2015.1012045

19. Meneghel SN, Moura R, Hesler, LZ, Gutierrez DMD. Tentativa de suicídio em mulheres idosas: uma perspectiva de gênero. Ciênc Saúde Coletiva. 2015;20(6):1721-30. doi: http://dx.doi.org/10.1590/1413-81232015206.02112015.

20. Marquetti FR, Marquetti FC. Suicídio e feminilidades. Cadernos Pagu. 2017;(49):e174921. doi: https://doi.org/10.1590/180944492017 00490021

21. Sociedade Brasileira de Geriatria e Gerontologia. Dia Mundial do Combate ao Suicídio: depressão entre idosos: precisamos falar sobre isso [Internet]. São Paulo: SBGG; 2016 [citado 2019 jun. 16]. Disponível em: https://sbgg.org.br/1009-dia-mundial-do-combate-ao-suicidiodepressao-entre-idosos-precisamos-falar-sobre-isso/

22. Nações Unidas Brasil. Suicídio é grave problema de saúde pública e prevenção deve ser prioridade [Internet]. Brasília: ONU; 2018 [citado 2019 jun. 16]. Disponível em: https://nacoesunidas.org/suicidio-e-grave-problema-de-saude-publica-e-prevencao-deve-ser-prioridadediz-opas-oms/

23. Schrijvers DL, Bollen J, Sabbe BGC. The gender paradox in suicidal behavior and its impact on the suicidal process. J Affect Dis. 2012;138 (1-2):19-26. doi: http://dx.doi.org/10.1016/j.jad.2011.03.050

24. Dantas ESO. Prevenção do suicídio no Brasil: como estamos? Physis. 2019;29(3):e290303. doi: https://doi.org/10.1590/s010373312019290303

25. The Global Burden of Disease. Injury collaborators: global mortality from firearms: 1990-2016. JAMA. 2018:;8(1):792-814. doi: http:// dx.doi.org/10.1001/jama.2018.10060

26. American Foundation for Suicide Prevention. Suicide statistics: additional facts about suicide in the US [Internet]. Washington; 2019 [cited 2019 June 16]. Available from: https://afsp.org/about-suicide/suicide-statistics/

27. Bernardes SS, Turini CA, Matsuo T. Perfil das tentativas de suicídio por sobredose intencional de medicamentos atendidas por um Centro de Controle de Intoxicações do Paraná, Brasil. Cad Saúde Pública. 2010;26(7):1366-72. doi: https://doi.org/10.1590/S0102$311 \times 2010000700015$

28. Pereira KG, Peres MA, lop D, Boing AC, Boing AF, Aziz M, et al. Polifarmácia em idosos: um estudo de base populacional. Rev Bras Epidemiol. 2017;20(2):335-44. doi: http://dx.doi.org/10.1590/1980-5497201700020013

29. Vidal CEL, Gontijo ECDM, Lima LA. Tentativas de suicídio: fatores prognósticos e estimativa do excesso de mortalidade. Cad Saúde Pública. 2013;29(1):175-187. doi: http://dx.doi.org/10.1590/S0102-311X2013000100020

30. Brooks SE, Burruss SK, Mukherjee K. Suicide in the elderly: a multidisciplinary approach to prevention. Clin Geriatr Med. 2019;35(1):13345. doi: https://doi.org/10.1016/j.cger.2018.08.012 